\title{
Korean War in the Turkish Press
}

\section{Sevinç Tekindor von zur Mühlen}

To cite this article: Sevinç Tekindor von zur Mühlen (2012) Korean War in the Turkish Press, Turkish Studies, 13:3, 523-535, DOI: 10.1080/14683849.2012.717448

To link to this article: http://dx.doi.org/10.1080/14683849.2012.717448

\section{Published online: 03 Oct 2012.}

Submit your article to this journal ๔

Џll Article views: 330

Q View related articles $\sqsubset$ 


\title{
Korean War in the Turkish Press
}

\author{
SEVINÇ TEKINDOR VON ZUR MÜHLEN \\ Department of International Relations, Faculty of Economics, Administrative and Social Sciences, \\ Bilkent University, Ankara, Turkey
}

\begin{abstract}
As the Korean War broke out in 1950, the decision to send a Turkish brigade to Korea was met with almost total acceptance by the Turkish people, although the opposition party criticized the decision-making process for not being legal. Among others, one reason for sending troops was to prove to the Western world the reliability and value of Turkey as a possible NATO member. This article analyzes the coverage of the outbreak and development of the Korean War, the state of the Turkish politics in 1950s, and the discussions surrounding the decision of entering the war in the Turkish press.
\end{abstract}

\section{Introduction}

On June 25, 1950, the North Korean military passed the 38th parallel which divided the Korean peninsula. This was the beginning of the Korean War. It was a war that took the world by surprise, creating a "Third World War" scare only five years after the Second World War, particularly when the Truman administration signaled the possible use of atomic bombs against North Korea. This "hot war" of the Cold War period had repercussions all over the world, as it brought the two camps of the Cold War, communist East and capitalist West, face-to-face in an armed conflict.

Like the rest of the world, the Korean War came as a shock to Turkey. Besides its obvious negative effects, the Korean War presented the young Republic with several opportunities. Being a United Nations (UN) member and a recipient of Marshall Aid from the USA, the Turkish government was still in need of improving its image as a reliable country needed by the Western alliance for maintaining peace and security in the world. Certainly, the Turkish government was seriously concerned with securing its independence and territory as Soviet Russia had demands on the Turkish Straits, as well as posing a possible communist threat to its domestic politics. ${ }^{1}$ With these concerns in mind, first, the İnönü administration, followed by the Menderes government, tried to find a way out of this security threat by seeking NATO membership. But particularly the Alliance's European members did initially not accept this, claiming that

Correspondence Address: Sevinç Tekindor von zur Mühlen, Department of International Relations, Faculty of Economics, Administrative and Social Sciences, Bilkent University, 06800 Ankara, Turkey. Email: sevinc@hotmail.com 
there were too many cultural and religious differences with Turkey. In this sense, participation in the Korean War, within the UN, presented Turkey with a timely opportunity to prove to the Western world that it could be a reliable ally and a valuable member of NATO.

The decision to send a Turkish brigade to Korea was met with almost total acceptance and approval by the Turkish people. From the very beginning of the war, the Turkish press displayed a great deal of attention to the event, presenting it as an aggression toward the "free world" by the communists, and supporting a Turkish presence in the war as a savior of that world. Discussions among politicians, intellectuals, and journalists took place in the press, and most of the articles about the issue had an obvious stance against communists—or "reds" as they were frequently called. The latest news about the war, received from international news agencies and radios, immediately appeared in print.

During the 1950s, the main Turkish newspapers were Milliyet, Cumhuriyet, Ulus, Zafer, Vatan, Akşam, and Hürriyet. Zafer supported the Democratic Party (DP, Demokrat Parti) - the governing party during the Korean War, whereas Ulus supported the Republican People's Party (CHP, Cumhuriyet Halk Partisi)—the major opposition party of the time. On the Korean question, all these prominent newspapers had similar viewpoints, although every now and then there were some diverging voices such as some editorials by former Foreign Minister Necmeddin Sadak of Akşam, and Professor Nihat Erim of Ulus. Both criticized the government's way of decision-making in sending Turkish troops to Korea, but not the decision itself.

This article evaluates the coverage of the Korean War in the Turkish press. It begins with the evolution and outbreak of the Korean War. Questions such as the rise of the Cold War, the advent of Communist China, and the division of Korea are discussed. Then, the state of Turkish politics in the 1950s, foreign policy concerns of the government, discussions concerning the decision to send Turkish troops to Korea, and the battles of the Turkish brigade in the region are discussed. As the main point of concern, reflections of all these developments in the Turkish press and the technical capacity of the press in reporting news about the war are analyzed. This study utilizes Turkish newspaper archives published during the war, memoirs of the commanders of the Turkish Brigade and combat correspondents in Korea, as well as selected secondary resources.

\section{Evolution and Outbreak of the Korean War}

The Second World War ended in 1945. It left 36 million people dead. It failed to bring total peace, giving way to the Cold War that would last for more than 40 years. The Korean War was the "hot" episode of the Cold War, creating a Third World War scare by possibly bringing the two sides of the Cold War into an armed conflict. ${ }^{2}$

When the Second World War ended in 1945, the Grand Alliance between the USA and Soviet Russia was swiftly crumbling. Differences over the Turkish Straits, the presence of Soviet troops in Iran, the types of government in parts of liberated Europe that was under Soviet control, and the question of Germany caused a 
chasm between the two allies. Overall, as soon as the Japanese and German dictatorships were defeated, mutual distrust began to characterize the East-West relations.

Even though a division between the US and the Soviets was undecided at first, the dispute reached the point of no return in 1947. President Truman had declared on March 12, 1947, in a speech that was later known as the Truman Doctrine, that it was the US responsibility to "support free peoples who are resisting attempted subjugation by armed minorities or by outside pressures."3 Truman delivered his historic speech in the Congress in an attempt to ask for the funds necessary to support friendly governments such as in Greece and Turkey. Certainly, American policymakers were anything but idealists. Their intention was to deny the Soviets proximity to the Middle East. As such, the Congress allocated \$400 million in military aid to Greece and Turkey. This was followed by Marshall Plan, a much more comprehensive aid plan for Western Europe.

Soon after the Second World War, Communists began to gain the higher ground in the civil war in China. The inept rule of Nationalist Chiang Kai-Shek, coupled with the determination and appeal of the Communist leader Mao Tse-Tung, was turning the tide to the latter's advantage. Together with the support he received from Moscow, Mao's successes culminated in victory in 1949, with the proclamation of the People's Republic of China on October 1st of that year. China would play an important role in the course of the Korean War.

A key reason for the Korean War was the physical division of Korea after the Second World War. As the invading Japanese armies withdrew from the peninsula, Americans occupied the south, while Soviets occupied the north. Negotiations for three years failed to reach a solution. The two sides established "friendly" governments in their territories and both withdrew their forces in 1948. The 38th parallel became the de facto border between the north and south. A young Marxist Kim IlSung ruled North Korea, while the South was governed by an aging pro-US Syngman Rhee. Determined to unite Korea under his rule, Kim met with Mao and Stalin in the early months of 1950 to discuss his plans. Even though he was not able to secure a firm military commitment from his comrades, neither Stalin nor Mao objected to Kim's proposed venture. ${ }^{4}$ On June 25, 1950, North Korean armies crossed the 38th parallel.

\section{Turkey in the Korean War and its Repercussions in the Turkish Press}

Through the diplomatic maneuvers and political skill of the National Chief İsmet Inönü, Turkey avoided getting involved in the Second World War, which would have had disastrous impacts on the social, political, and economic life of the young Republic. In the 1940s and the 1950s, Turkey was experiencing changes in its domestic politics, a transition from a single-party to a multi-party system. ${ }^{5}$ Turkey was fast becoming a battlefield in the Cold War between the USA and Soviet Russia, as both countries vied to have Turkey on their side. While Americans supported Turkey with Marshall Aid, Russians were trying to strike a deal with the 
Turkish government on the use of the Turkish Straits, hoping to secure an advantageous position for themselves.

The Korean War started in an inappropriate environment in Turkish political life. There were several reasons for this, but the transition from a single-party to multiparty system was the main cause. After 27 years of CHP government under the leadership of National Chief İsmet İnönü, the victory of DP in the general elections, and the formation of the first Menderes government on May 22, 1950, opened a new era in Turkish political life.

The DP government, with Prime Minister Adnan Menderes and Minister of Foreign Affairs, Fuad Köprülü, came to office only 40 days before the outbreak of the Korean War. Neither had held such high political offices before and thus were inexperienced in domestic and foreign policy. The new government was institutionally a member of the Western world, by membership in several international organizations. Domestic economic development was a priority on their agenda.

Application to NATO membership, a process started by the İnönü government after the then Foreign Affairs Minister Necmeddin Sadak had intense talks with President Truman for Turkish accession to the Pact in March 1949, was an indicator of such a Western approach. On August 1, 1950, Turkey formally applied to NATO, as Ankara wanted to be under NATO's security umbrella against the Soviet threat. However, this request was declined, for reasons such as cultural and religious differences, and the geographical location of Turkey, which was not a North Atlantic country. In his memoirs, George Kennan commented on the issue as follows,

...It is not our policy to encourage the adherence to it of any country not properly a part of the North Atlantic area... It was true that the regimes in Greece and Turkey were anti-communist. But to make that, and that alone, a criterion for admission to the pact seemed to me a dangerous precedent. Nor could they — particularly the Turkish government—have qualified for membership on the standard of association with our ideas of democracy and individual liberty. ${ }^{6}$

Still, in those days, Turkish statesmen and journalists saw membership in NATO mostly as a necessity for protecting Turkish security; and through editorials and press statements of politicians, newspapers communicated these views to the public. Selim Sarper, the then permanent representative of Turkey in the UN, in a press conference, stressed that Turkey was determined to join the Atlantic Pact and that the government spared no effort to this end. ${ }^{7}$

The outbreak of the Korean War and the possibility of a troop contribution were in a way an opportunity for the new government to improve Turkey's image in the international arena, and to support the cause of Turkey's accession to NATO. As indicated by John M. Vander Lippe, "as Turkey sought a closer alliance with the Western Powers, participation in the Korean War meant not only membership in the Western bloc but also confirmation of Western ideals and the westernizing reforms of the Republican government." ${ }^{\prime 8}$ This was also in line with the agenda of the new 
DP government. The relationship between sending troops to Korea and becoming a member of NATO was also fostered by American politicians such as Senator Cain, whose statement in Akşam was pointing exactly to this: “Turkey's help to Korea will improve Turkey's honor in the world and would provide its acceptance to the Atlantic Pact."

The "image" question of Turkey on the international arena was a real concern for the Turkish politicians as it presented a major obstacle toward a closer alliance with the Western powers. The root of the problem was the insistence of the Turkish state, which remained neutral during the Second World War, despite the pressure from Roosevelt and Churchill. Particularly, they demanded that Turkey enter the war on their side, basing their claim on the agreement signed between France, Britain, and Turkey on October 19, 1939, which stated that if Italy attacked France and Britain, Turkey would enter the war. However, with the help of the reservations that Turkey included in the agreement, Inönü managed to keep Turkey out of the devastation of the Second World War. ${ }^{10}$ Of course, neutrality came with a price: Turkey was labeled as an "unreliable" state by the Western powers. This image of Turkey was also presented in an article written by Time magazine correspondent Jim Bell in 1951:

Turkey emerged from World War II lonely and friendless. It had played the hard-to-get neutral, declaring war on Nazi Germany only at the last moment, in February 1945, in time to qualify for U.N. membership. It was cut from the Balkans and the Arab World too, and isolated from Islam. No one loved Turks. The Turks loved no one. ${ }^{11}$

A troop contribution to the Korean War was an invaluable opportunity for the DP government, which made extensive efforts to reverse the unpleasant image of Turkey, an obstacle on the way of NATO membership. Particularly, the words of the Minister of Foreign Affairs, Fuad Köprülü, to the US Ambassador to Turkey, George Wadsworth, in the face of the first casualty figures-30 percent of the Turkish Brigade was lost—showed the extent of the Turkish government's willingness to improve Turkey's image and to become a NATO member: "Don't feel sorry for us, Mr. Ambassador. This is a most wonderful thing for Turkey. Since World War II, the world has been saying that Turkish soldiers were no good. Now the world will know we can fight, and will fight."12

Editorial writer of Zafer, Mümtaz Faik Fenik, was among those who supported Turkey's membership to NATO. Although he underlined that Turkey's decision to send troops to Korea did not have anything to do with receiving more aid from the West, in an editorial on July 30, 1950, he admitted that participating in the war would have a positive impact for Turkey's image in the eyes of West.

...With our decision to send a squad of 4500 soldiers to Korea, news regarding Turkey's accession to the Atlantic Pact has refreshed, and in a couple of days, satisfactory telegrams from Washington regarding this issue has started to come. 
Yes, for today, Turkey's accession to the Atlantic Pact has turned into a necessity. This has become an important point to stress for preventing dangers in Turkey and for protecting the European continent. ${ }^{13}$

The DP government, with a significant media support behind it, seized the opportunity when the UN issued a resolution asking member states to help South Korea against North Korean aggression. When North Korea passed the 38th parallel and invaded South Korea, the USA wanted the UN to issue a resolution against this aggression. With the Soviet Union in the Security Council this would not be possible. But, luckily for the USA, at that moment, Soviet representative, Yakov Malik, was absent from the Security Council. For six months, he had been boycotting the presence of Nationalist China's representative in the Security Council, instead of one from Communist China. On June 27, 1950, the UN Security Council, in the absence of the Soviet delegate, issued resolution 83 , recommending member states to assist South Korea,

Having determined that the armed attack upon the Republic of Korea by forces from North Korea constitutes a breach of peace,

Having called for an immediate cessation of hostilities,

Having called upon the authorities in North Korea to withdraw forthwith their armed forces to $38^{\text {th }}$ parallel,

Having noted from the report of the United Nations Commission on Korea that the authorities in North Korea have neither ceased hostilities nor withdrawn their armed forces to the $38^{\text {th }}$ parallel, and that urgent military measures are required to restore international peace and security,

Having noted that the Republic of Korea to the United Nations for immediate and effective steps to secure peace and security.

Recommends that the Members of the United Nations furnish such assistance to the Republic of Korea as may be necessary to repel the armed attack and to restore international peace and security in the area. ${ }^{14}$

On June 28, 1950, Minister of Foreign Affairs, Fuad Köprülü, replied to the call of the Norwegian UN General Secretary, Trygve Lie, for assistance in Korea with a telegram. This telegram was later printed in all newspapers, announcing Turkey's willingness and readiness to satisfy the obligations with "utmost sincerity" stemming from UN membership. ${ }^{15}$ This affirmative answer showed the inclination of the DP government toward sending troops to Korea. This generated intense debates in political circles, particularly, between the government and the opposition party, as well as in the media, among editorial writers.

Abidin Daver, editorial writer of Cumhuriyet, was strongly in favor of strengthening ties with the West, and he saw the Korean issue as a means to achieve this. In his editorial on July 15, 1950, he emphasized this point,

...we have to believe that when there is an attack on our country tomorrow, all United Nations will rush for our help. For this reason, it will not be right to 
think that to make a symbolic help to Korea, like sending wheat and drugs, will be sufficient. Because, like this, we will open the doors for receiving only symbolic aid in return when we are attacked. ${ }^{16}$

Whereas the former Minister of Foreign Affairs, Necmeddin Sadak, also owner and editorial writer of Akşam, was hesitant about sending troops to Korea, on the grounds that Turkey could not afford this materially; nor was it certain that this would mean a guarantee of UN support in case of an attack on Turkey. In his editorial on July 16, 1950, he referred to Daver's editorial of the previous day,

In today's conditions, actual and serious aid of any use of an Eastern Mediterranean country to the Pacific is neither logical nor possible.

...

Nobody can think of a serious aid from Turkey to Korea. There is no material possibility of this. Turkey has vital reasons for this. In the world conditions of today, Turkey cannot afford to spare any manpower, weapons or supplies to send to the Far East.

...

If Turkey gets attacked, nobody will come to help us seriously just because we helped Korea. It will be a dream to believe and to trust this.

...

Everybody knows Turkey's delicate situation. And even if we attempt to spare power for Korea, we are sure that our friends and allies will not allow this. ${ }^{17}$

Just a couple of days after these comments, on July 18, 1950, the DP government, in a meeting in Yalova, made the decision to send troops to Korea. President Celal Bayar, Prime Minister Adnan Menderes, Vice-PM Samet Ağaoğlu, Minister of Foreign Affairs Fuad Köprülü, Minister of National Defense Refik Şevket İnce, Chief of the Staff General Nuri Yamut met for six hours, and arrived at a consensus to enter into the war. This decision had a shocking impact in Turkish political life, as the opposition party CHP, especially the National Chief İsmet İnönü felt bypassed, since it was made without consulting the Grand National Assembly.

Although, CHP in general, and İnönü in particular was not against sending troops to Korea, they opposed the procedure and started to question the legality of the decision. Inönü, in a press statement to Hürriyet declared that,

It would have been our wish that as a president of a party which stayed in power for many years, the government would consult me. In grand problems regarding the state, like its defense and possibilities of war, governments' positional agreement with the opposition party is the basic measure for maintaining the unity of the state... Moreover, regarding this issue, the government did not even ask the opinion of the Grand National Assembly. ${ }^{18}$

Of course, the DP government defended its position, and insisted that there was no need to ask the Grand National Assembly for permission, as the decision was 
in line with the UN declaration that the GNA had previously ratified. Menderes and his supporters argued that what İnönü actually did not like was that the Prime Minister did not ask his "personal" opinion on the matter, and that he was not really concerned with the procedural problem of not bringing the matter to the GNA. Prime Minister Menderes' comments on the issue were covered by newspapers:

... actually, today, the decision of the government is a natural result of the path they [CHP] took and the obligations that they went under. Moreover, if it were them, they could not have made a decision different from this one...

We would wish that, in the face of a state matter of such importance, they understand that the unpleasant path they took with the aim of hitting their rivals and getting close to power can jeopardize our country... ${ }^{19}$

Discussions around the legality of the decision also took place between the editorial writers of Ulus and Zafer, which supported the CHP and DP, respectively. In his column, Nihat Erim stressed that the decision of the government was in conflict with the Turkish Constitution:

Did the government stay within the boundaries of jurisdiction drawn by our Constitution and laws while taking this decision?

An answer can be given to this question clearly: The government, by announcing the decision of sending 4500 Turkish soldiers to the Korean front to be included in war efforts under the order of the United Nations headquarters, without presenting it to the approval of the Grand National Assembly, to the United Nations General Secretary as a final decision, went beyond the boundaries of authority drawn by our Constitution. ${ }^{20}$

Still, in line with the general spirit of sending troops, in another article, Erim made it clear that he was not against sending troops to Korea, and that the safety of the country should be above all domestic political bickering:

In short, in the way things go, necessitates us to direct all our attention to international events. To whatever degree the bickering over domestic issues gets heated, in face of the life and death danger seen on the horizon, these should not have any importance.

There is no doubt that both the government and the opposition are patriotic and have common sense. While discussing our domestic issues, we cannot neglect the danger which threatens our nation's existence. ${ }^{21}$

Mümtaz Faik Fenik of Zafer, supporter of DP government, did not refrain from answering comments such as Erim's and interpreted them as attacks solely aimed for wearing down the Menderes government: 
The opposition now, takes up this decision [of sending troops to Korea] as a political issue, and attacks the Democratic Party government by beating about the bush.

The reason is this: Why did they not consult the opposition while making this decision?

Let's consider that they did [consult the opposition], in case the opposition opposed, would the government deny the UN declaration that they signed?

Let's stop gossiping and do not use this noble act for small political games. ${ }^{22}$

In such an atmosphere, on August 3, 1950, the Turkish Brigade (241st infantry regiment, artillery battalion, and other support units) gathered in Ankara to be trained for the Korean venture. ${ }^{23}$ On September 25, 1950, (the first company), 26 (the second company), and 29 (the third company), with the Turkish Brigade, under the command of General Tahsin Yazici and the 241st regiment commander, Colonel Celal Dora, set off from the port of İskenderun toward South Korea. They reached their destination, the port of Pusan, almost 23 days later. This news made headlines a couple of days later due to security considerations. ${ }^{24}$

Reaching Korea, the Turkish Brigade, under the command of the American forces, was assigned its first task, which was to patrol the Taegu region. This was not an easy task as people escaping from North to South were not only villagers, but also Chinese and North Korean guerrillas dressed like South Korean villagers. In addition, the language barrier created huge problems.

From November 7, 1950, onwards, Turkish forces were assigned another task and were put under the command of the eight Legion of the 25th American Division, which was under the command of General Walton Walker. The task was to ensure the safety of the right wing of this American division during their retreat from Pyongyang - capital of North Korea, which was necessitated as a result of a massive Chinese attack that had started on the 6th of November.

The Turkish soldiers fought in several battles, but one in particular stands out. The Turkish Brigade, entitled the "North Star Brigade" by the Americans, ${ }^{25}$ started its march toward the North and reached Kunu Ri, at the Chosin Reservoir, on the 26th of November, which would be the day of the one of the bloodiest battles of the entire war. That day, with a sudden Chinese attack, American and South Korean units almost surrendered, and it was up to the Turkish Brigade to try to save them. Due to logistic and communication problems with the American units, the Turkish Brigade was left to its own fate. The American units left their equipment and fled from the area, without giving notice to the Turkish units. During November 26-30, Turkish forces engaged in a hand-to-hand fierce fight with a strong Chinese army, and managed to break the Chinese siege. By November 30, half of the Brigade was lost-either dead, wounded, lost, or had become POWs. ${ }^{26}$ Still, the actions of this heroic and courageous Turkish unit had a significant impact throughout the world. As a result, the Brigade received the American Distinguished Unit Citation.

Back in Turkey, these heroic actions of the Turkish forces were widely covered in the newspapers as another moment of heroism in Turkish military history, but there 
was not much emphasis on the losses. From the very beginning of the Korean War, all Turkish newspapers covered the issue with great interest, mostly using information received from news agencies such as the Associated Press and Anatolian News Agency. Based on this common flow of information, almost all of the newspapers relayed identical news. On June 26, 1950, a day after the war broke out, both Hürriyet and Milliyet printed articles retrieved from news agencies, "war broke out in Korea" and "yesterday actual war broke out in Korea," respectively. Besides the news agencies, another source of information was broadcasts from foreign radios, which gave information regarding the war, and newspaper correspondents would prepare the next day's issues accordingly.

Of course, in order to get first-hand information, some newspapers sent combat correspondents to the war zone, but that was a rare practice when compared to today. Among them, there were Hikmet Feridun Es and his wife Semiha Es (photographer) for Hürriyet, Faruk Fenik for Cumhuriyet, Selami Akpınar for Vatan, and Poyrazoğlu for Zafer. Also, Altemur Kılıç, Press and Information Officer of the Turkish Brigade in 1952, sent voice records from Korea to Turkey. Moreover, there were Turkish journalists, based in European capitals, who followed the news in the foreign press and reported directly to their newspapers in Turkey. An example of this was Metin Toker, Western Europe correspondent of Cumhuriyet and Zafer in the 1950s. Consequently, headlines such as "Le Figaro: Turks, who entered war two days ago showed wonderful heroism" or "Le Monde: Turks who fight wonderfully broke Chinese siege with their bayonets" appeared in Turkish newspapers. ${ }^{27}$

Considering that the Korean War was not in proximity to the Turkish borders, and that the heavy casualties the Turkish Brigade suffered were causing so much pain back home, newspapers were eager to publish articles which would touch the hearts of the Turkish people; particularly, families of the soldiers. Reporting on the daily lives of Turkish soldiers in Korea was an attempt to soften the harsh war effects on soldiers' families. Combat correspondents prepared serials of this sort, publishing letters sent from Korea, showing what Mehmetcik(s) did in their leisure time, how and what they ate and drank. They also sent articles about the culture, language, and daily life of the local South Korean people.

Poyrazoğlu for Zafer prepared a serial titled "Kore Mektupları (Korea Letters)," where he wrote about his impressions about Korea, the conduct of the war, and the daily lives of our Turkish soldiers. In one of his articles, he reported that Mehmetcik(s) were not able to understand the currency of Korea yet, but that they devised a barter system, where two cigarettes cost an apple. Another time, he reported that Mehmet$c i k(s)$ started to learn Korean, and that they say "haşim nika" instead of "hi.",28

Like Zafer, Hürriyet also sent combat correspondents, Hikmet Feridun Es and his wife Semiha Es, the first female combat photographer in the world, to Korea on November 16, 1950. Hürriyet was a relatively new newspaper, and it attracted many readers particularly by publishing lots of photos, including colored ones. Hikmet Feridun Es also prepared a series of articles, decked with plenty of photos taken by his wife, entitled "Hikmet Feridun Es Kore'de Mehmetçik'i Adım Adım Takip Ediyor [In Korea Hikmet Feridun Es Follows Mehmetcik(s) Step-by-Step]." 
He would show Mehmetcik(s) dining, playing instruments, sleeping, writing letters and, of course, preparing for combat.

\section{Conclusion}

Between September 20, 1950, and August 20, 1953, Turkey sent a total of three brigades to South Korea, all of which represented their country with great honor. By the end of the war, the toll was 721 dead, 2147 wounded, 234 prisoners of war, and 175 lost in action. ${ }^{29}$ This tragic picture has been scratched in the hearts and minds of Turkish people, and took its honorable place in Turkish military history. With their heroic and courageous actions, the Turkish Brigade, called "Brave of the Braves" by General MacArthur, ${ }^{30}$ successfully carried out the task of improving the image of Turkey in the international arena, loyal to the initial idea behind the decision of the DP government to send Turkish troops to Korea, and paved the way for Turkey's NATO membership, which was to happen on February 18, 1952.

During the course of the war, Turkish media also successfully carried out its task of informing; in a way comforting people back in Turkey and creating a favorable public opinion toward war on communism. With the limited technical capabilities of that time, the Turkish press, by using combat correspondents, telegrams, radio broadcasts, and information gathered from news agencies, did its job. Along with the general population's approval in favor of sending troops to Korea, newspapers of the time-Vatan, Zafer, Hürriyet, Cumhuriyet, Milliyet, Ulus, Akşam - all supported the decision of the DP government to partake in the Korean War. In the initial stages, there were some opposing voices - such as Ulus and Akşam editorials-about the procedures used in the decision-making, but these never overshadowed the common understanding about the necessity of being a part of the Korean War. Turkey had made a vital choice.

\section{Notes}

1. These concerns were voiced mainly during the Second World War, and there are no indications that these demands were still valid in the 1950s. However, these demands were used by the Menderes government for strengthening the Turkish position as an ally of the USA.

2. For a history of the Korean War, see William Stueck, Rethinking the Korean War: A New Diplomatic and Strategic History (New Jersey: Princeton University Press, 2004).

3. Address of the President to Congress, Recommending Assistance to Greece and Turkey (March 12, 1947). Harry S. Truman Administration, http://www.trumanlibrary.org/whistlestop/study_ collections/doctrine/large/documents/index.php?pagenumber=4\&documentdate=1947-03$12 \&$ documentid=5-9

4. For a concise rendition of this process, see John Lewis Gaddis, We Now Know (Oxford: Clarendon, 1997).

5. For details, see Kemal Karpat, Turkey's Politics: The Transition to Multi-party System (Princeton: Princeton University Press, 1959).

6. George Kennan, Memoirs 1925-1950 (USA: Little, Brown \& Company, 1967), p. 411.

7. "Atlantik Paktına Girmek İstiyoruz [We Want to Join the Atlantic Pact]," Akşam, (July 28, 1950), p. 3. Feridun Cemal Erkin, then the Turkish Ambassador to the USA, provides a comprehensive account of the diplomatic efforts in his memoirs; Feridun Cemal Erkin, Les Relations Turco-Soviétiques et la Question des Détroits (Ankara: Başnur, 1968). 
8. John M. Vander Lippe, "Forgotten Brigade of the Forgotten War: Turkey's Participation in the Korean War," Middle Eastern Studies, Vol. 36, No. 1 (January 2000), pp. 92-102.

9. "Senatör Cain'in Beyanatı [Senator Cain's Statement]," Akşam (July 26, 1950), p. 1.

10. These reservations were mainly as follows: No obligation can force Turkey to enter war against the Soviet Union; and allies have to make sufficient military and financial aid if Turkey is going to be included in the war.

11. Jim Bell, "Turkey: Strategic and Scrappy," Time (October 15, 1951), p. 32.

12. Ibid.

13. Mümtaz Faik Fenik, "Azimli Politikamız ve Atlantik Paktı [Our Determined Policy and the Atlantic Pact]," Zafer (July 30, 1950), p. 1.

14. United Nations, 83 (1950). Resolution of June 27, 1950 [S/1511].

15. In a meeting, 53 out of 56 member states of the $\mathrm{UN}$ at the time gave an affirmative reply in principle to this call. USSR, Czechoslovakia, and Poland were the exceptions.

16. Abidin Daver, Cumhuriyet (July 15, 1950), p. 1.

17. Necmeddin Sadak, "Kore Savaşı ve Türkiye [Korean War and Turkey]," Akşam (July 16, 1950), pp. $1-2$.

18. "İnönü'nün Kore Kararı Hakkındaki Demeci [The Statement of İnönü regarding the Korean Decision]," Ulus (July 29, 1950), pp. 1 and 3.

19. "Adnan Menderes Kararı Müdafaa Etti [Adnan Menderes Defended the Decision]," Ulus (July 29, 1950), pp. 1 and 4.

20. Nihat Erim, "Birleşmiş Milletler Anayasası ve Son Karar [The Constitution of the United Nations and the Final Decision]," Ulus (July 29, 1950), pp. 3-4.

21. Nihat Erim, "Her Şeyin Üstünde Dış Selamet [Foreign Safety Above Everything]," Ulus (July 20, 1950), p. 3.

22. Mümtaz Faik Fenik, Zafer (July 28, 1950), pp. 1 and 8.

23. For details, see İbrahim Artuç, Kore Savaşlarında Mehmetçik [Mehmetcik at the Korean Wars] (İstanbul: Kastaş, 1990); Kore Harbinde Türk Silahl Kuvvetlerinin Muharebeleri (1950-1953) [The Battles of the Turkish Armed Forces During the Korean War (1950-1953)], T.C. Genelkurmay Harp Tarihi Başkanlığı, Resmi Yayınları Seri No. 7 (Ankara: Gnkur, 1975); Kore: Kore'de Cereyan Eden Muharebelerden Alinacak Dersler [Korea: The Lessons that should be taken from the Battles taking place at Korea], T.C. Genelkurmay Askeri Tarih ve Stratejik Etüt Başkanlığı, Askeri Tarih Yayınları, (Ankara: Gnkur, 1979); Kore'de Türk Askeri [Turkish Soldier in Korea], T.C. Genelkurmay Askeri Tarih ve Stratejik Etüt Başkanlığı, Türk Asker Büyükleri ve Türk Zaferleri Seri No. 17 (Ankara: Gnkur, 1989); Tahsin Yazıc1, Kore Birinci Türk Tugayında Hatıralarım [My Memories in the first Turkish Brigade in Korea] (İstanbul: Ülkü, 1963); Celal Dora, Kore Savaşında Türkler [Turks in the Korean War] (İstanbul: İsmail Akgün, 1963); Mim Kemal Öke, "Unutulan Savaş"ın Kronolojisi: Türkler ve Kore, 1950-1953 [The Chronology of "the Forgotten War": Turks and Korea, 1950-1953] (İstanbul: Simurg, 2000); Tuna Baltacıoğlu, Savaş İçinde Barış: Kore Savaşı Anıları: Yaşantı [Peace within War: Korean War Memories: Experience] (İstanbul: Yapı Kredi Yayınları, 2000).

24. Altan Öymen, Değişim Yılları [The Years of Change] (İstanbul: Doğan, 2004), p. 560.

25. Altemur Kılıç, Kıllı̧'tan Kllıç'a: Bir Dönemin Tanıklığı [From Kılıç to Kılıç: Witnessing a Period] (İstanbul: Remzi, 2005), p. 170.

26. POW (Prisoner of War).

27. Metin Toker, DP'nin Altın Ylllart: 1950-1954 [The Golden Years of DP: 1950-1954] (Ankara: Bilgi, 1991), p. 105.

28. Poyrazoğlu, "Kore Mektupları—Kore'de İlk Günlerimiz [Korean Letters-Our First Days in Korea]," Zafer (November 18, 1950).

29. Kore Harbinde Türk Silahl Kuvvetlerinin Muharebeleri (1950-1953) [The Battles of the Turkish Armed Forces During the Korean War (1950-1953)], T.C. Genelkurmay Harp Tarihi Başkanlığı, Resmi Yayınları Seri No. 7 (Ankara: Gnkur, 1975), p. 417.

30. Quoted in Altemur Kılıç, Kllıç’tan Kıllıç'a: Bir Dönemin Tanıklığı [From Kılıç to Kılıç: Witnessing a Period] (İstanbul: Remzi, 2005), p. 175. 


\section{Notes on Contributor}

Sevinç Tekindor von zur Mühlen is a $\mathrm{PhD}$ candidate in the Department of International Relations at Bilkent University, Ankara. She received her BA in International Relations in 1998 and her MA in International Relations in 1999, both from Bilkent University, Ankara. She received her MA in Political Science in 2002 from McGill University, Montreal. Her research interests include international migration policies, German politics, European Union, and international political economy. 